\title{
Millennial-Scale Response of a Western Mediterranean River to Late Quaternary Climate Changes: A View from the Deep Sea
}

\author{
Lucile Bonneau, ${ }^{1,2, \star}$ Stéphan J. Jorry, ${ }^{2}$ Samuel Toucanne, ${ }^{2}$ \\ Ricardo Silva Jacinto, ${ }^{2}$ and Laurent Emmanue ${ }^{1}$
}

1. Laboratoire Biominéralisations et Environnements Sédimentaires, Université Pierre et Marie Curie; and Institut des Sciences de la Terre de Paris, Paris, France; 2. Laboratoire Environnements Sédimentaires, Institut français de recherche pour l'exploitation de la mer, F-29280 Plouzané, France

\begin{abstract}
A B S T R A C T
Although it is widely accepted that erosion and sediment transfer respond to millennial-scale climatic variability, these changes remain difficult to detect in marine sedimentary archives. In the Var sediment-routing system, northwestern Mediterranean Sea, the absence of a continental shelf results in a direct connection between the Var River mouth and the deep basin during both highstand and lowstand conditions. This makes the Var sedimentrouting system an ideal target to test whether rivers can transmit climate-driven high-frequency changes in sediment flux to the ocean. On the basis of an unprecedented (centennial-to-millennial-scale) resolution in turbidite sequences, we reconstructed the activity of turbidity current overflows along the deep-sea Var Sedimentary Ridge over the past 75 kyr. The overflow activity is highest (one event every 10-30 yr) during maximum glacial conditions (30 kyr-16 kyr ago [ka]) and rapidly decreases (down to one event every 100-500 yr) during the last glacial-interglacial transition (Termination 1). During marine isotope stage (MIS)4 and MIS3 (75-30 ka), peaks in the overflow activity occurred synchronously with cold and arid Dansgaard-Oeschger stadials, while warmer and wetter interstadial conditions correspond to low overflow activity. We conclude that overflow activity on the Var Sedimentary Ridge mainly reflects changes in the magnitude of hyperpycnal currents flowing in the turbiditic channel-levee system in relation with variations in suspended-sediment concentration during Var River floods. We show that this signal is sensitive to changes in pure sediment flux induced by climatic perturbations occurring inland: (1) the decrease in glacier-derived sediment input after glacier retreat and (2) changes in erosion induced by shifts in the vegetation cover in response to Dansgaard-Oeschger climate swings.
\end{abstract}

\section{Introduction}

Sediment delivery to the ocean results from the balance between sediment production by erosion and transfer/storage by fluvial systems (Schumm 1977; Castelltort and Van Den Driessche 2003). Since the last glacial period (after $80 \mathrm{kyr}$ ago [ka]), southern Europe has repeatedly undergone drastic climatic changes that have affected land surfaces, including glacial termination (i.e., Termination 1, from ca. $20 \mathrm{ka}$ to $10 \mathrm{ka}$; Hinderer 2001; Moreno et al. 2012; Sternai et al. 2013) and Dansgaard-Oeschger (D/O) cycles (e.g., Allen et al.

\footnotetext{
Manuscript received October 3, 2013; accepted June 2, 2014; electronically published October xx, 2014.

* Author for correspondence; e-mail: lucile.bonneau@upmc
}

1999; Sánchez-Goñi et al. 2002; Fletcher and Sánchez-Goñi 2008; Fletcher et al. 2010; Macklin et al. 2012), and have probably resulted in changes in the sediment budget delivered to the ocean (Kettner and Syvitsky 2008, 2009). These changes remain difficult to detect from the marine sedimentary archives because of the strong overprint exerted by the concomitant sea-level changes and the subsequent emergence/flooding of continental shelves that directly affects the morphology of sediment-routing systems (e.g., drainage basin area, hypsometry, and delta migration; Blum and Törnqvist 2000) and their ability to deliver sediment to the ocean (Mulder and Syvitsky 1996; see, e.g., Toucanne et al. 2012 for the western European margin). Therefore, the response of sedimentary systems to Late Quaternary climate changes

[The Journal of Geology, 2014, volume 122, p. 000-000] @ 2014 by The University of Chicago. All rights reserved. 0022-1376/2014/12206-00XX\$15.00. DOI:10.1086/677844 
is usually highlighted in close proximity with the erosion zone, such as in lacustrine records (e.g., Hinderer 2001; Hinderer and Einsele 2001; Collier et al. 2000), or in fluvial incision/aggradation phases (e.g., Macklin et al. 2012 for a thorough review). As a result, large uncertainties remain concerning the ability of fluvial systems to transmit the signal of millennial-scale perturbations to the ocean (Castelltort and Van Den Driessche 2003; Meybeck and Vörösmarty 2005; Allen 2008; Jerolmack and Paola 2010; Simpson and Castelltort 2012; Armitage et al. 2013; Coulthard and Van de Wiel 2013).

In this context, small, mountainous rivers draining active margins with narrow shelves could provide interesting study sites to investigate climatic control of the amount of sediments delivered to the ocean (Allen 2008; Romans et al. 2009; Covault et al. 2010, 2011). Because sediment transfers are mostly ensured by periodic floods and because their floodplains and deltas/estuaries are reduced in size, these rivers are more likely to discharge larger percentages of their sediment loads directly to the sea (i.e., a lesser proportion of sediments is sequestered before entering the sea) than do large rivers (Milliman and Syvitsky 1992; Mulder and Syvitsky 1996; Allen 2008). Thereafter, sediments can easily escape the narrow shelves and feed deep basins during both high and low stands of sea level (Milliman and Syvitsky 1992; Mulder and Syvitsky 1996). Recent studies focusing on the terminus of short sediment-routing systems along the Toyama Deep-Sea Channel (Japan; Nakajima and Itaki 2007) and on the Newport deep-sea depositional system (California; Covault et al. 2010) have shown that during specific intervals, climate changes alone could have controlled the sedimentary inputs and the turbidite activity, with minor impact from sea level fluctuations. This highlights that, in addition to lacustrine and fluvial environments, deep-sea sediment accumulation in short sediment-routing systems can be used to investigate the response of terrestrial surface erosion to climate changes.

In this study, we focus on the sediment deposition pattern of the Var sediment-routing system (fig. 1), located in the northwestern Mediterranean Sea, where the absence of a continental shelf resulted in the direct connection between the Var river mouth and the deep basin during both highstand and lowstand conditions (Savoye et al. 1993). On the basis of sedimentary cores with high-resolution stratigraphic frameworks, we reconstructed the Late Pleistocene-Holocene temporal changes of unconfined turbidity-current ac- tivities off the Var River, more precisely on the deep-sea turbiditic levee (Var Sedimentary Ridge [VSR]). The results are compared with proxy records of climate and terrestrial erosion in the western Mediterranean realm in order to examine whether rapid climate changes have driven the sedimentflux variability.

\section{The Var Sediment-Routing System}

The Var sediment-routing system extends from the upper reaches of the southern French Alps (up to $3000 \mathrm{~m}$; fig. 2) to the deep Ligurian Sea in the Var turbiditic system that ends near the continental slope of Corsica at a water depth of $2700 \mathrm{~m}$ (fig. 1). The southern French Alps margin is characterized by a very narrow continental shelf $(2-3 \mathrm{~km}$ maximum; figs. 1, 2), which is even absent near the Var River mouth, off Nice. The continental slope is steep (up to $16 \%$ ) and is incised by two main submarine canyons, the Var Canyon and the Paillon Canyon, directly connected to the Var and Loup Rivers and to the Paillon River, respectively. These canyons merge into a single upper valley at the base of the continental slope. The deep depositional system includes a prominent levee (the VSR) on the right-hand bank of the middle valley and a distal lobe at the end of the lower valley (fig. 1).

The Var River (120 km long; fig. 2) is the main contributor of sediment to the deep depositional system (Migeon et al. 2012). Annual sediment discharge of the Var River is estimated between 1.32 and 1.63 million tons/yr (Mulder et al. 1997b, 1998). The Var drainage area (ca. $2800 \mathrm{~km}^{2}$ ) is located on the edge between the Mediterranean and alpine domains and is characterized by a steep slope (mean slope: $23^{\circ}$ ). Carbonate rocks from the alpine foreland form the downstream part of the river basin, while igneous/metamorphic rocks of external alpine massifs form the upstream areas (Mercantour Massif; figs. 1, 2). The high sediment yield (about 500 tons $/ \mathrm{km}^{2} / \mathrm{yr}$ ) is mostly associated with episodic floods, which can reach a magnitude $\left(>800 \mathrm{~m}^{3} / \mathrm{s}\right)$, larger than the mean annual discharge $\left(70 \mathrm{~m}^{3} / \mathrm{s}\right)$, in only a few hours (Dubar and Anthony 1995). Floods mainly occur in autumn, during the heavy rainfall season, and in spring, when snow melts (Sage 1976). In 1994, a catastrophic, highmagnitude flood (200-yr flood) transported in a few hours the amount of sediment that is normally transported in 11-14 yr (Mulder et al. 1997b, 1998).

Holocene marine sedimentation rates reconstructed near the Var River mouth are a fraction (between $1 / 11$ and $1 / 39$ ) of those predicted by sedimentation models, thus revealing that the sedi- 


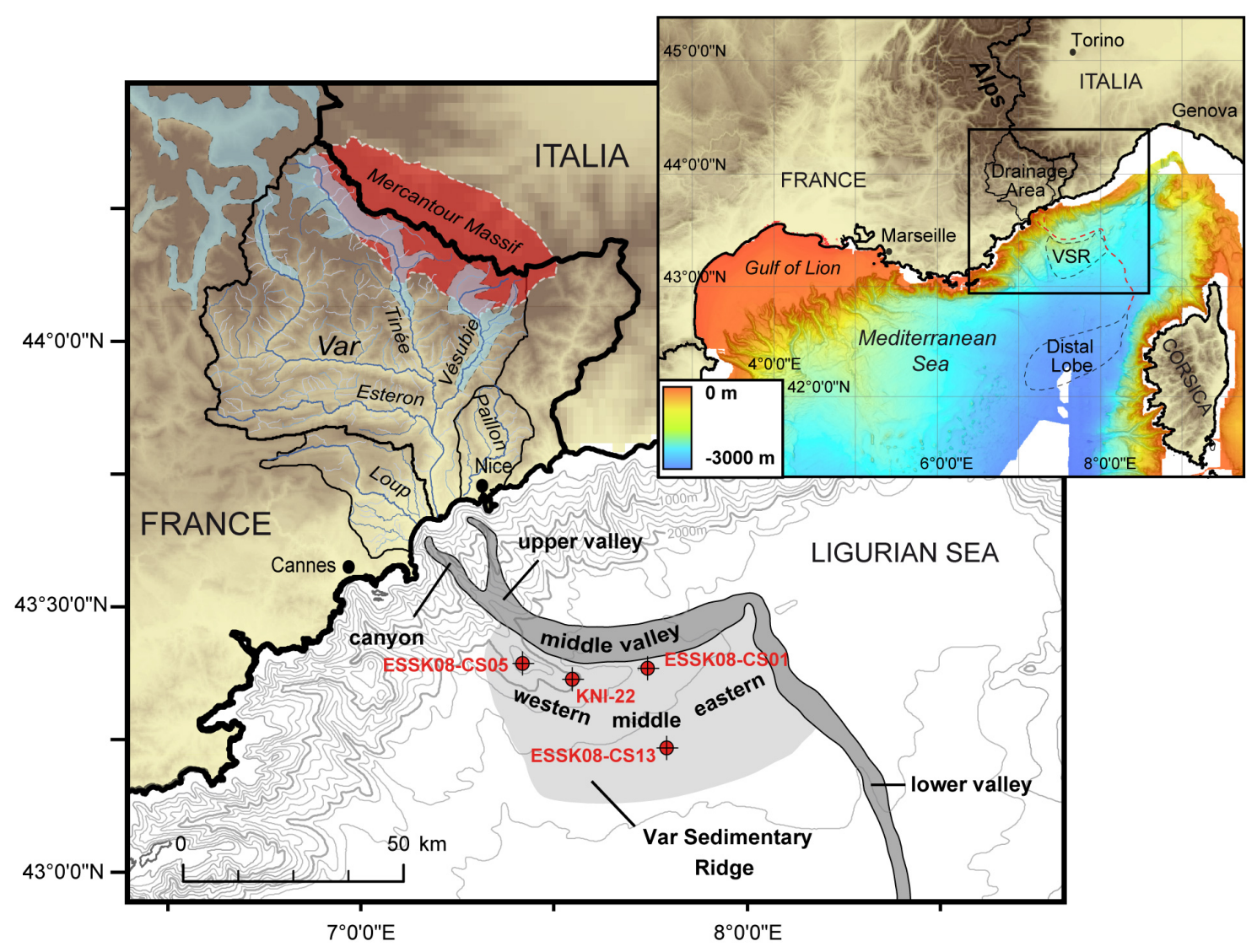

Figure 1. Map of the Var sediment-routing system, showing the location of the four studied sites. The glacier cover during the Last Glacial Maximum is highlighted as pale areas with dashed outlines in the upper river valleys; the metamorphic massif of Mercantour is represented by the area circled by white dashed line. A color version of this figure is available online.

ments were poorly trapped in the Var delta and on the upper slope during highstand conditions (preservation rate $<9 \%$; Mulder et al. 1997b, 1998). After entering the sea, the major part of the sediment is evacuated toward the turbidite system directly by hyperpycnal flow of Var flood currents initiated at the Var River mouth during episodic floods or is reworked after being deposited for a short time period (a few weeks to a few years; Mulder et al. 1998) into slide-induced turbidity currents (Piper and Savoye 1993; Savoye et al. 1993; Khripounoff et al. 2009, 2012).

Recent monitoring in the Var Canyon and in the valley revealed that both low-magnitude hyperpycnal flows and small, slide-induced turbidity currents can occur once or twice a year at present (Khripounoff et al. 2009, 2012). These lowmagnitude/high-frequency flows rapidly die in the canyon or the upper valley (Khripounoff et al. 2009, 2012). On the basis of a 20-yr hydrological record
(1974-1994), Mulder et al. (1997b) estimated that up to $63 \%$ of sediments delivered at the Var River mouth were exported through hyperpycnal currents, making them the main sediment transfer processes in the Var turbidite system.

High-magnitude flows that could produce a significant deposit (i.e., wide and thick enough to be preserved in the sediment record) include (1) hyperpycnal flows of exceptional high-magnitude floods of the Var River and (2) turbidity currents initiated by the transformation of mass-wasting processes affecting a large portion of the continental slope (Piper and Savoye 1993; Mulder et al. 1997b, 1998, 2001a, 2001b; Migeon et al. 2012). The best-known example of type 2 is the 1979 failure in the Nice airport area, which was triggered after landfilling operations (Dan et al. 2007). Nevertheless, the latter type of event was shown to be secondary, because the study of sedimentary sequences deposited during the past century on a 


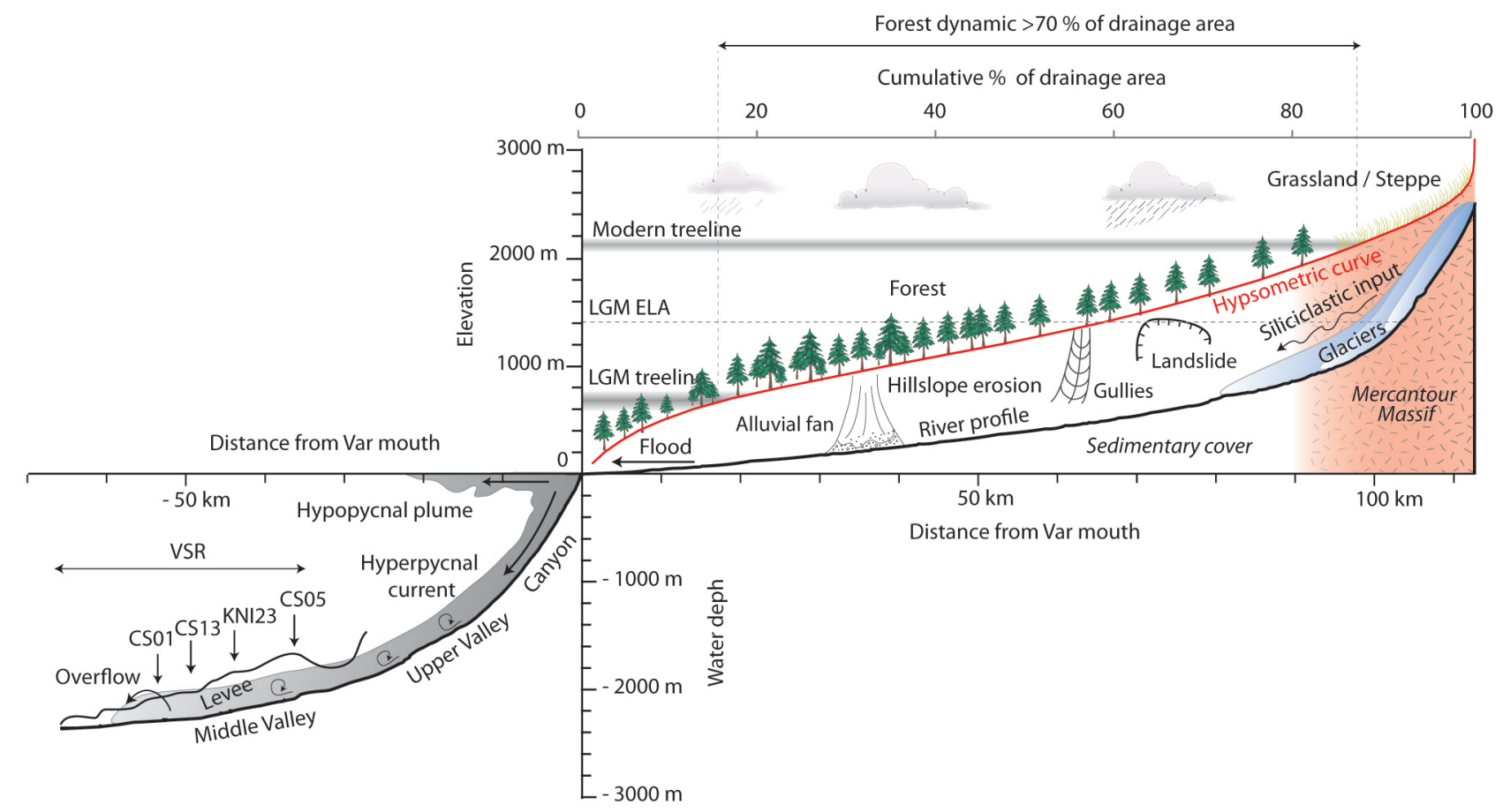

Figure 2. Synthetic profile of the Var sediment-routing system. The black line indicates the topographic/bathymetric profile of the sediment pathway in the Var sediment-routing system. Sediment cores used in this study (ESSK08-CS01, ESSK08-CS05, ESSK08-CS13, and KNI-22) have been projected along the crest of the Var Sedimentary Ridge (VSR). The hypsometric curve of the Var watershed (gray line) shows that $70 \%$ of the drainage area span in the tree dynamic domain between modern and hypothetical Last Glacial Maximum (LGM; located under maximum extend altitude of glaciers) tree line elevations. ELA = equilibrium line altitude of glaciers during the LGM, adapted from Kuhlemann et al. (2008). A color version of this figure is available online.

terrace of the Var canyon revealed that deposition was mainly dominated by hyperpycnal-flow deposits $(\sim 70 \%$ of the sedimentary column; one event every $7 \mathrm{yr}$ ), likely to be connected with historical floods of the Var River $\left(>1200-\mathrm{m}^{3} / \mathrm{s}\right.$ floods with a theoretical return period ranging from 3 to $21 \mathrm{yr}$; Mulder et al. 2001b). Most of these events are not recorded on the VSR because of the inability of most flows to overtop the ridge wall (Mulder et al. 1998). Indeed, in the middle valley, the VSR crest reaches $300 \mathrm{~m}$ above the main channel floor in its western part, and its height decreases eastward down to a few tens of meters. The rapid construction during the past $900 \mathrm{kyr}$ required regular supply by overflow of high-magnitude flows (Savoye et al. 1993). At present, overflow events are rare (Mas 2009). Both turbidity-current-related and hyperpycnal-current-related deposits were found in Holocene sediments cored on the VSR (Migeon et al. 2001), but unlike those on the terrace of the Var Canyon (Mulder at al. 2001b), recent deposition processes on the VSR are not dominated by hyperpycnal currents (around $6 \%$ of turbidite beds; Migeon et al. 2012). Hyperpycnal currents may have been more active on the VSR during the Pleistocene (Piper and Savoye 1993; Mulder et al. 1998), because such prominent levees are most seen in fans with strong glacial input, such as the Laurentian fan, in which the hyperpycnal flows of fluvioglacial discharge result in high, asymmetric levee systems (Skene and Piper 2003).

\section{Material and Methods}

Sediment Cores. This study is based on four sediment cores recovered on the western and middle VSR: three Calypso long piston cores (ESSK08CS01, ESSK08-CS05, and ESSK08-CS13) collected during the 2008 ESSDIV cruise on board the research vessel (R/V) Pourquoi pas? (Institut français de recherche pour l'exploitation de la mer [IFREMER]) and an additional core (KNI-22) retrieved with a Kullenberg piston corer during the 1996 NICASAR cruise on board the R/V Le Suroitt (IFREMER). Cores ESSK08-CS05, ESSK08-CS01, 
and KNI-22 were collected along the levee crest; core ESSK08-CS13 is located on the southwestern flank of the VSR (fig. 1). The location and coring characteristics of each core are described in table 1.

Recognition of turbidite beds is based on visual description. Core ESSK08-CS05 is located on the uppermost part of the VSR, where levee height exceeds $300 \mathrm{~m}$ (fig. 2). The whole core is composed of hemipelagic mud and rare, very thin millimetric silt beds (fig. 3b). In cores ESSK08-CSO1 and KNI-22, the upper $5 \mathrm{~m}$ are mainly composed of hemipelagic mud and a few turbidite beds, mainly fine-grained, while numerous sandy beds, alternating with silt mud, are described in the lower part of the cores (figs. 3b, 4). Core ESSK08-CS13, located on the southern flank of the VSR about $20 \mathrm{~km}$ from the middle valley (fig. 1), shows rich turbidite bed intervals alternating with thick hemipelagic facies (figs. 3b, 4). Core ESSK08-CS01, located on the lowermost part of the VSR crest about $130 \mathrm{~m}$ above the canyon floor (fig. 2), contains the highest number of turbidite beds. The cumulative length of sandy/silt beds (i.e., Tc of the Bouma sequence; Bouma 1962) is negligible in core ESSK08-CS05, while it represents about $15 \%$ in KNI-22, 30\% in ESSK08-CS13, and $40 \%$ of the total length in ESSK08-CS01 (fig. 3b).

Stratigraphic Framework. Planktonic foraminifers Globigerina bulloides have been used to establish the chronostratigraphic framework and have been picked every $10 \mathrm{~cm}$ in hemipelagic layers. When the turbidites were too dense and the resumptions of hemipelagic deposition were not clear (e.g., core ESSK08-CS01; fig. 4), samples have been taken in the uppermost part of the turbidite sequence (Te-d of the Bouma sequence; Bouma 1962), where the lithic sand content theoretically is absent and no foraminifers transported by turbidity currents can be found (Zaragosi et al. 2006). However, the sand fraction $(>125 \mu \mathrm{m})$ was checked after washing and before the picking of foraminifers. Samples with a large content of lithic grains $(>20 \%)$ were removed in order to avoid analysis of allochtonous foraminifers.

The oxygen isotopic composition of G. bulloides was measured on a few specimens (3-5 shells) weighing from 20 to $50 \mu \mathrm{g}$. $\mathrm{CO}_{2}$ was extracted with a Kiel IV carbonate device, and analyses were performed on a DELTA V isotope ratio mass spectrometer at the Pierre and Marie Curie University (Paris). Isotope values are reported in delta notation relative to Vienna Peedee belemnite. Repeated analyses of a marble working reference (calibrated against the international reference NBS-19) show an accuracy and precision of $0.1 \%(1 \sigma)$. The oxygen isotope curves of the first $7 \mathrm{~m}$ of cores ESSK08CS013, ESSK08-CS05, and KNI-22 were previously published by Jorry et al. (2011).

Radiocarbon accelerator mass spectrometry (AMS) dating was provided by the Poznan Radiocarbon Laboratory (Poland) and the Laboratoire de Mesure du Carbone 14 (Commissariat à l'énergie atomique et aux énergies alternatives [CEA] Saclay, Gif-sur-Yvette, France) and was measured on about $10 \mathrm{mg}$ of $G$. bulloides or bulk planktonic foraminifers (see details in table 2). The ${ }^{14} \mathrm{C}$ ages were calibrated with Calib.06 software and the IntCal09 calibration curve (Reimer 2009; table 2). A reservoir age of $400 \mathrm{yr}$ was used. Calibrated kiloyears before present are referred to as age "ka" in this contribution.

Geochemical Analyses. In core ESSK08-CS05, Xray fluorescence (XRF) semiquantitative element data were produced on an Avaatech XRF core scanner at IFREMER (France) at a step size set of $1 \mathrm{~cm}$. Two measurements were performed, both counting times being integrated over $10 \mathrm{~s}$. The first measurement was realized with an X-ray current of $600 \mathrm{~mA}$ and $10 \mathrm{kV}$, giving access to light elements such as $\mathrm{Al}, \mathrm{Si}, \mathrm{Ca}, \mathrm{Cl}, \mathrm{S}, \mathrm{Ti}, \mathrm{K}, \mathrm{Mn}$, and $\mathrm{Fe}$. The second measurement, using an X-ray current of $1000 \mathrm{~mA}$ and $30 \mathrm{kV}$, measured Rb, Sr, and Zr. Element abundance is expressed in count rate (area). Principal-component analysis (PCA) was carried out with an XRF core-scanner data set of 12 independent geochemical variables (1876 cases) in order to describe the main variance of the data set, providing common trends observed for each element. The first eigenvector of PCA, accounting for $58.5 \%$ of the total variance, displays low Ca values associated with high positive scores for $\mathrm{Al}, \mathrm{Si}, \mathrm{K}$, $\mathrm{Ti}, \mathrm{Fe}, \mathrm{Rb}$, and $\mathrm{Zr}$, the latter elements being present

Table 1. Location, bathymetry, and length of the studied cores

\begin{tabular}{lllllrr}
\hline Core & Cruise & Research vessel & Latitude & Longitude & Water depth $(\mathrm{m})$ & Length $(\mathrm{cm})$ \\
\hline KNI-22 & NICASAR & Le Suroît & $43^{\circ} 21.75^{\prime} \mathrm{N}$ & $7^{\circ} 32.63^{\prime} \mathrm{E}$ & 1900 & 849 \\
ESSK08-CS01 & ESSDIV & Pourquoi Pas? & $43^{\circ} 23.24^{\prime} \mathrm{N}$ & $7^{\circ} 44.181^{\prime} \mathrm{E}$ & 2130 & 1052 \\
ESSK08-CS05 & ESSDIV & Pourquoi Pas? & $43^{\circ} 23.60^{\prime} \mathrm{N}$ & $7^{\circ} 25.190^{\prime} \mathrm{E}$ & 1694 & 2878 \\
ESSK08-CS13 & ESSDIV & Pourquoi Pas? & $43^{\circ} 14.922^{\prime} \mathrm{N}$ & $7^{\circ} 47.817^{\prime} \mathrm{E}$ & 2473 & 2450 \\
\hline
\end{tabular}




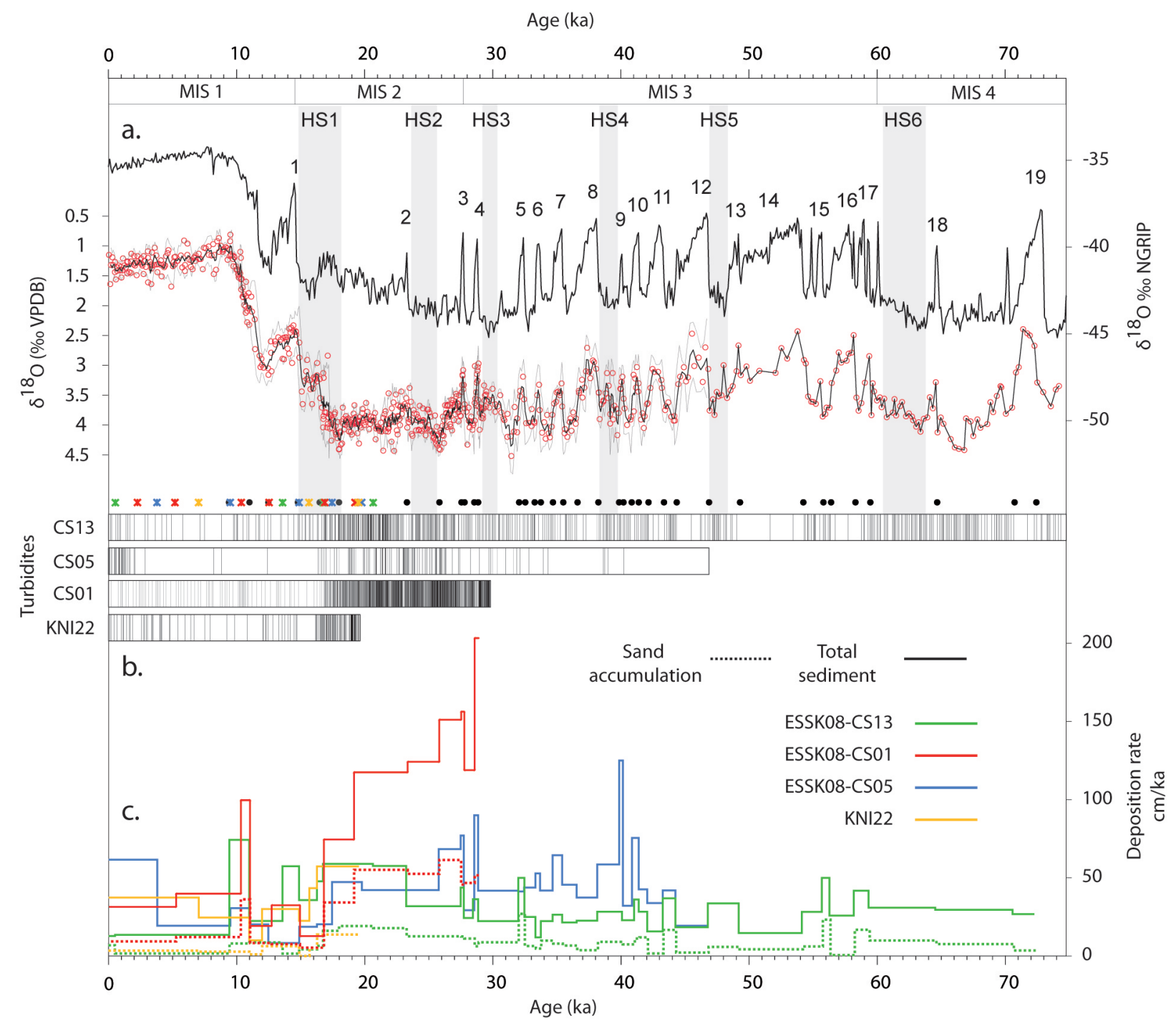

Figure 3. $a$, Composite $\delta^{18} \mathrm{O}$ curve (upper line; right-hand scale) of Globigerina bulloides, derived from the stack of data obtained in all cores (circles on lower line; left-hand scale). The core age model is anchored by ${ }^{14} \mathrm{C}$ accelerator mass spectrometry dates (asterisks at bottom of panel; see table 1 for details) and has been refined using the tuning of the G. bulloides $\delta^{18} \mathrm{O}$ curves with the $\delta^{18} \mathrm{O}$ record from the North Greenland Ice Core Project (NGRIP) ice core isotopes curve (Greenland Ice Core Chronology 2005 [GICC05] up to $60 \mathrm{kyr}$ ago [ka], NGRIP thereafter; NGRIP Members 2004; Rasmussen et al. 2006; Svensson et al. 2008). Tie points are represented by filled circles at the bottom of the panel; the open circles correspond to tie points used in the 0-20-ka chronostratigraphy previously established by Jorry et al. (2011). b, Interpolated age of turbidite sequences for the four sediment cores. c, Sedimentation rate (solid lines) and sand accumulation (dotted lines; except for core ESSK08-CS05, where sand content is negligible). The numbers 1-19 mark interstadials. HS = Heinrich stadials; $\mathrm{MIS}=$ marine isotope stage; VPDB = Vienna Peedee belemnite. A color version of this figure is available online.

mainly in detrital silicates (table 3). The position of each sample on the first PCA axis (PCA axis 1) allows us to qualitatively reconstruct the evolution of siliciclastic input (e.g., Moreno et al. 2008). Finally, samples with a high score are interpreted to represent siliciclastic-rich material (i.e., eroded from the upper part of the Var River basin and the metamorphic massif of Mercantour in particular; see the discussion below).

\section{Turbidite Stratigraphic Framework}

The variations of planktonic oxygen isotopes reveal a consistent correlation between the four 
ESSK08-CS13

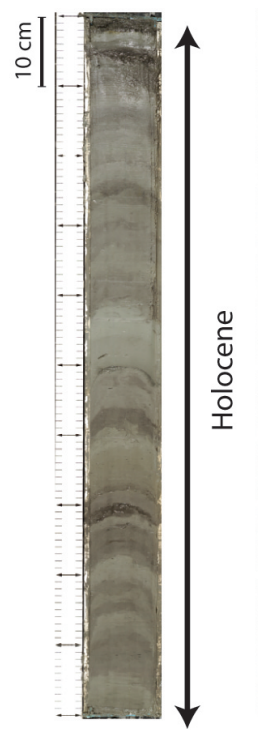

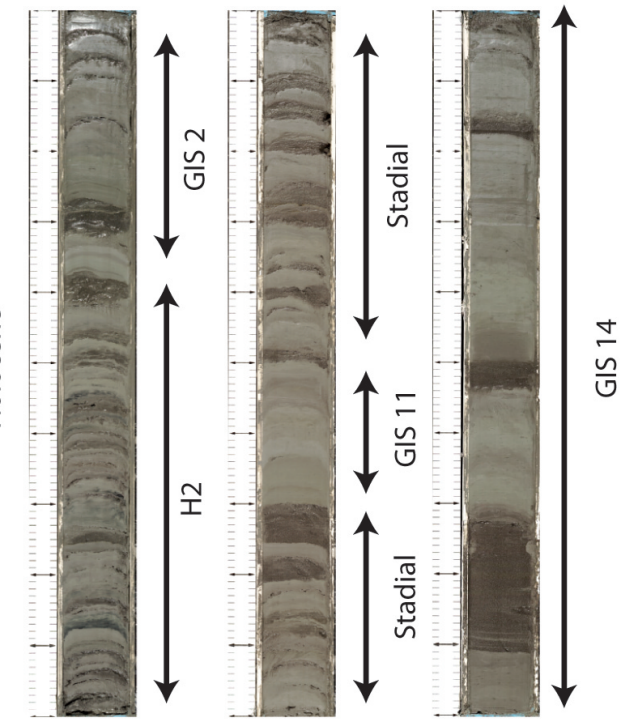

ESSK08-CS01

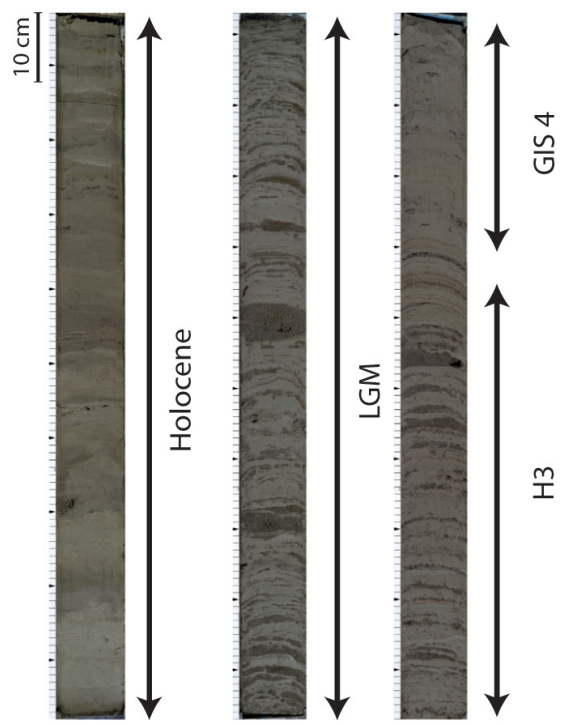

Figure 4. Examples of sedimentary facies observed in cores ESSK08-CS13 and ESSK08-CS01. Low turbidite frequencies are observed during Holocene and Greenland interstadials (GIS), whereas the highest frequencies are found during Last Glacial Maximum (LGM), glacial stadials, and Heinrich stadials (H2, H3). A color version of this figure is available online.

coring sites. This shows that erosion by turbidity current processes has a limited impact on the preservation and continuity of the stratigraphic record all along the VSR. The age models are established by tuning Globigerina bulloides $\delta^{18} \mathrm{O}$ records with the North Greenland Ice Core Project (NGRIP) ice core isotopes record (Greenland Ice Core Chronology 2005 [GICC05] up to $60 \mathrm{ka}$, NGRIP thereafter; NGRIP Members 2004; Rasmussen et al. 2006; Svensson et al. 2008). This synchronization is based on the striking resemblance between the data sets, which points out the synchronicity between the Mediterranean climate oscillations (e.g., $\mathrm{D} / \mathrm{O}$ oscillations) and the North Atlantic climate changes (Cacho et al. 1999; Martrat et al. 2004). Tie points are located both at the transitions from stadial (cold) to interstadial (warm) D/O events and at those from interstadial to stadial ones, as given by Sierro et al. (2009) for the northwestern Mediterranean domain (fig. 3a). The age model of the 0 $20-\mathrm{ka}$ period is based on the VSR chronostratigraphy established by Jorry et al. (2011) through integration of AMS radiocarbon dating (table 2; fig. $3 a$ ). To avoid bias in age models, specifically when the sedimentation rate is low, thick turbidite beds $(>3 \mathrm{~cm})$ were removed from linear interpolation between age tie points. The ${ }^{14} \mathrm{C}$ AMS ages from 20 to $40 \mathrm{ka}$ strongly support the chronology detailed here (table 2). Because of the unambiguous correlation of the planktonic $\delta^{18} \mathrm{O}$ records between the four coring sites, a composite isotopic record was generated (fig. $3 a$ ). The latter, used as the VSR isotopic curve reference in the following discussion, encompasses the past $75 \mathrm{kyr}$ (i.e., Marine Isotope Stages [MIS] 4-1) and perfectly records the D/O variability, thus providing an unprecedented resolution in turbidite sequences (fig. 3a). This definitively shows that turbidite systems are able to provide a consistent chronological framework, even at millennial-scale resolution. From this point, we used the Var sediment-routing system as a natural laboratory to investigate the response of fluvial transfers to millennial-scale climate oscillations.

\section{Multiscale Turbidite Depositional Variations}

On the basis of age models, an age was attributed to each turbidite bed (fig. $3 b$ ), allowing a 100-yr sliding model of 500-yr turbidite frequency to be built. This allows the identification of variations in the turbidite frequency at a millennial scale (figs. 5f, 6c).

Fluctuating turbidite frequency of the VSR indicates highest frequencies during maximum glacial conditions, i.e., from the end of MIS 3 (ca. $30 \mathrm{ka}$ ) to the first part (18-16 ka) of Heinrich Stadial $1(\sim 18-$ $14.7 \mathrm{ka})$. The turbidite frequency rapidly decreases (by four-fifths) thereafter, i.e., during Termination 
Table 2. List of Radiocarbon Ages Used in This Study

\begin{tabular}{|c|c|c|c|c|c|c|}
\hline Core, lab code ${ }^{a}$ & Foraminifer type & $\begin{array}{c}\text { Depth } \\
\text { (cm bsf) }\end{array}$ & $\begin{array}{c}\text { AMS }{ }^{14} \mathrm{C} \text { age } \\
(\text { yr } \mathrm{BP})\end{array}$ & $\begin{array}{c}\text { Error } \\
\text { (yr) }\end{array}$ & $\begin{array}{c}\text { Cal age } \\
(\mathrm{ka})\end{array}$ & $\begin{array}{c}\delta^{18} \mathrm{O} \text { NGRIP-tuned } \\
\text { age }(\mathrm{ka})\end{array}$ \\
\hline \multicolumn{7}{|l|}{ ESSK08-CS13: } \\
\hline Poz-51828 & Globigerina bulloides & 6.5 & 795 & 30 & .51 & \\
\hline Poz-33994 & G. bulloides & 300.5 & 12,080 & 180 & $13.59^{\mathrm{b}}$ & \\
\hline Poz-34446 & G. bulloides & 447.5 & 13,930 & 70 & $16.76^{b}$ & \\
\hline Poz-34150 & G. bulloides & 678.5 & 17,720 & 100 & $20.68^{b}$ & \\
\hline Poz-51830 & G. bulloides & 833.5 & 19,550 & 340 & 22.92 & 23.33 \\
\hline Poz-51832 & G. bulloides & 883.5 & 21,670 & 140 & 25.43 & 25.08 \\
\hline Poz-51833 & G. bulloides & 957.5 & 23,230 & 330 & 27.53 & 27.33 \\
\hline Poz-51834 & G. bulloides & 1044.5 & 27,250 & 250 & 31.29 & 30.85 \\
\hline Poz-51835 & G. bulloides & 1107.5 & 29,210 & 310 & 33.44 & 32.82 \\
\hline Poz-51836 & G. bulloides & 1170.5 & 30,040 & 340 & 34.34 & 35.64 \\
\hline SacA 31588 & G. bulloides & 1231.5 & 33,080 & 260 & 37.16 & 38.36 \\
\hline SacA 31589 & G. bulloides & 1297.5 & 34,780 & 350 & 39.43 & 40.82 \\
\hline \multicolumn{7}{|l|}{ ESSK08-CS05: } \\
\hline Poz-33960 & G. bulloides & 234.5 & 3,805 & 30 & $3.80^{\mathrm{b}}$ & \\
\hline Poz-33962 & G. bulloides & 345.5 & 8,805 & 35 & $9.53^{\mathrm{b}}$ & \\
\hline Poz-33989 & G. bulloides & 436.5 & 13,090 & 180 & $14.91^{\mathrm{b}}$ & \\
\hline Poz-34445 & G. bulloides & 486.5 & 14,770 & 80 & $17.48^{\mathrm{b}}$ & \\
\hline Poz-33992 & G. bulloides & 596.5 & 17,070 & 100 & $19.81^{b}$ & \\
\hline SacA 29450 & G. bulloides & 785.5 & 21,260 & 80 & 24.90 & 24.30 \\
\hline SacA 29451 & G. bulloides & 950.5 & 23,290 & 100 & 27.63 & 27.30 \\
\hline SacA 29452 & G. bulloides & 1099.5 & 26,750 & 130 & 31.08 & 30.41 \\
\hline SacA 29453 & G. bulloides & 1340.5 & 30,620 & 180 & 34.85 & 35.62 \\
\hline SacA 29454 & G. bulloides & 1440.5 & 32,310 & 220 & 36.55 & 38.09 \\
\hline \multicolumn{7}{|l|}{ ESSK08-CS01: } \\
\hline SacA 31580 & Bulk plankton & 65.5 & 2,130 & 30 & 2.22 & \\
\hline SacA 29455 & G. bulloides & 163.5 & 4,840 & 30 & 5.20 & \\
\hline SacA 29456 & Bulk plankton & 366.5 & 9,405 & 30 & 10.28 & \\
\hline SacA 33155 & G. bulloides & 470.5 & 11,130 & 90 & 12.68 & \\
\hline SacA 33156 & G. bulloides & 566.5 & 13,960 & 100 & 16.78 & \\
\hline SacA 33157 & G. bulloides & 742.5 & 16,310 & 80 & 19.14 & \\
\hline SacA 31581 & Bulk plankton & 945.5 & 18,410 & 80 & 21.50 & 20.86 \\
\hline SacA 31582 & Bulk plankton & 1258.5 & 20,700 & 80 & 24.28 & 23.52 \\
\hline SacA 31583 & G. bulloides & 1440.5 & 21,720 & 80 & 25.49 & 24.98 \\
\hline SacA 31584 & Bulk plankton & 1626.5 & 22,820 & 90 & 27.21 & 26.36 \\
\hline SacA 31585 & G. bulloides & 1787.5 & 24,170 & 100 & 28.38 & 27.43 \\
\hline SacA 31586 & Bulk plankton & 1960.5 & 25,440 & 120 & 29.96 & 28.70 \\
\hline SacA 31587 & G. bulloides & 2135.5 & 26,530 & 140 & 30.92 & 29.56 \\
\hline \multicolumn{7}{|l|}{ KNI-22: } \\
\hline Poz-33957 & G. bulloides & 263.5 & 6,540 & 80 & $7.05^{b}$ & \\
\hline Poz-33958 & G. bulloides & 475.5 & 13,440 & 60 & $15.72^{\mathrm{b}}$ & \\
\hline Poz-33959 & G. bulloides & 689.5 & 16,880 & 80 & $19.59^{\mathrm{b}}$ & \\
\hline
\end{tabular}

Note. $\quad$ AMS = accelerator mass spectrometry; bsf = below sea floor; NGRIP = North Greenland Ice Core Project. AMS ${ }^{14} \mathrm{C}$ ages are calibrated (cal age) with Calib06 software using the Intcal09 calibration curve and a reservoir age of 400 yr. Only ${ }^{14} \mathrm{C}$ ages between 0 and $20 \mathrm{kyr}$ ago (ka) were integrated in age models; the equivalent $\delta^{18} \mathrm{O}$ NGRIP-tuned ages of other ${ }^{14} \mathrm{C}$ ages are also reported.

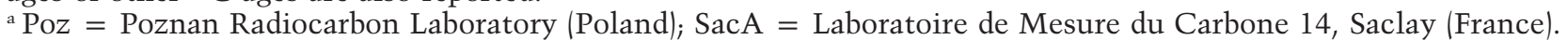

b Published by Jorry al. (2011).

1 (with the maximum decrease centered at $16 \mathrm{ka}$ ) and reaches minimum values during the Early Holocene (11.7-5 ka; fig. 5f).

In detail, the VSR turbidite frequency during MIS 4 and MIS 3 shows a strong correlation with the climatic variations recorded in the planktonic $\delta^{18} \mathrm{O}$ record (figs. 4, 6). Peaks in the turbidite frequency occurred synchronously with $\mathrm{D} / \mathrm{O}$ stadials (5-10 turbidites/500 yr at site ESSK08-CS13), while interstadial conditions corresponded to low turbidite frequencies (0-5 turbidites/500 yr). As a result, the turbidite activity seems to be directly connected to $\mathrm{D} / \mathrm{O}$ climate perturbations, according to a cold-high/warm-low turbidite activity pattern (fig. 6). The latter relationship is emphasized by the fact that frequencies as low as those encountered during the Early Holocene are reached when interstadial conditions are maintained long enough, 
Table 3. Principal-Component Analyses (PCA) Calculated for X-Ray Fluorescence Core Scanner Data for Core ESSK08-CS05

\begin{tabular}{lc}
\hline Element & PCA 1 score \\
\hline Aluminum (Al) & .887 \\
Silicon (Si) & .890 \\
Sulfur (S) & -.615 \\
Chlorine (Cl) & -.794 \\
Potassium (K) & .890 \\
Calcium (Ca) & -.484 \\
Titanium (Ti) & .949 \\
Manganese (Mn) & .346 \\
Iron (Fe) & .812 \\
Rubidium (Rb) & .830 \\
Strontium (Sr) & -.760 \\
\hline
\end{tabular}

Note. Factor load for each variable in the first main axis (PCA 1 score). A high positive score is found for elements commonly represented in siliciclastic rocks (Si, $\mathrm{Al}, \mathrm{K}, \mathrm{Ti}, \mathrm{Fe}$, and $\mathrm{Rb}$ ). The value of every sample defined on the first PCA axes enables us to qualitatively reconstruct the evolution of siliciclastic input recorded in the Var Sedimentary Ridge (figs. 4, 5).

precisely during $\mathrm{D} / \mathrm{O}$ interstadials $8,12,14,16$, and 19 . As a consequence, frequencies of $\mathrm{D} / \mathrm{O}$ cycles 5 $12(47-30 \mathrm{ka})$ seem to be modulated by the socalled Bond cycles (Bond et al. 1993), during which maximum turbidite activity is coeval with Heinrich stadials (fig. 6).

\section{Discussion}

Do Temporal Variations of Turbidite Deposits on the VSR Reflect Changes in Sediment Input at the River Mouth? Our results show that deep turbidite accumulation seems to respond to climatic changes at centennial-to-millennial timescales (figs. 5, 6). Nevertheless, before drawing conclusions about the mechanisms driven by climate changes that control sediment erosion and transfer in the Var sediment-routing system, it is important to define to what extent temporal variations in turbidite deposits on the VSR reflect changes in sediment input at the river mouth.

On the VSR, vertical accumulation (in a single core) of turbidites reflects variations in overflow activity of turbidity currents through time. On the other hand, the increase in the number of turbidite beds and sand content eastward (downstream; from core ESSK08-CS05 to ESSK08-CS01, located at about 300 and $130 \mathrm{~m}$ above the canyon floor, respectively; figs. $3 b, 3 c, 5 f)$ is likely caused by the gradual decrease of the elevation of the VSR, which becomes less and less effective at confining the flows (Piper and Savoye 1993; Migeon et al. 2001; Dennielou et al. 2006; fig. 2).
Only low-frequency/high-magnitude flows, both flood-induced (hyperpycnal current) and slideinduced (turbidity current), can spill over the top of the VSR and deposit a bed that could be preserved at geological timescales. As a result, the turbidite frequency variations recorded on the VSR may reflect changes in the magnitude of flows rather than the frequency of events triggered in the system (Piper and Normark 1983; Skene et al. 2002). The most recent example of overflow occurred during the 1979 event, but that was limited to the eastern end of the VSR, whose height is about a few tens of meters (Mulder et al. 1997a). In the western and middle part of the VSR, where the studied cores are located (fig. 1), the height of the levee exceeds $100 \mathrm{~m}$ (fig. 2). The capacity for turbidity current to mobilize a sufficient amount of sediments to overflow the ridge crest in this part of the VSR is the concomitant triggering of a large number of failures by an earthquake, which could then coalesce to form a huge turbid cloud (Piper and Savoye 1993; Mulder at al. 1997b, 1998). As a result, turbidite deposits observed in cores are considered to result from (1) large slide-induced turbidity currents triggered by earthquakes and (2) hyperpycnal currents following high-magnitude Var River floods (Piper and Savoye 1993; Mulder at al. 1997b, 1998). The two types of related deposits (i.e., Bouma-type turbidites and hyperpycnites, respectively) were not discriminated, and turbidite is used as general term in the text in this study.

A major change in the frequency of turbidite deposits is observed at $16 \mathrm{ka}$ in each studied core (figs. $3 b, 5 f$ ). The sharp decrease in the turbidite frequency after $16 \mathrm{ka}$ is associated with a change in turbidite bed type, which become finer grained and thinner. This change in sedimentation could be induced by a change in type of currents (mainly in magnitude) flowing in the middle valley (Piper and Savoye 1993; Migeon et al. 2012). Previously attributed to the Pleistocene-Holocene boundary, this transition has been reported in numerous cores recovered in the Var sedimentary system (Piper and Savoye 1993; Savoye et al. 1993; Migeon et al. 2001, 2006, 2012; Jorry et al. 2011).

After $16 \mathrm{ka}$, overflows on the western and middle VSR were rare, about one event every $100-500 \mathrm{yr}$ (fig. 5f). Moreover, numerous thick, turbiditic, sandy beds are found on the distal part of the system (eastern VSR and distal lobe) during the Holocene interval (Piper and Savoye 1993; Migeon et al. 2001, 2006, 2012). On the basis of this observation, we assume that slide-induced turbidity currents predominantly flowed in the middle 


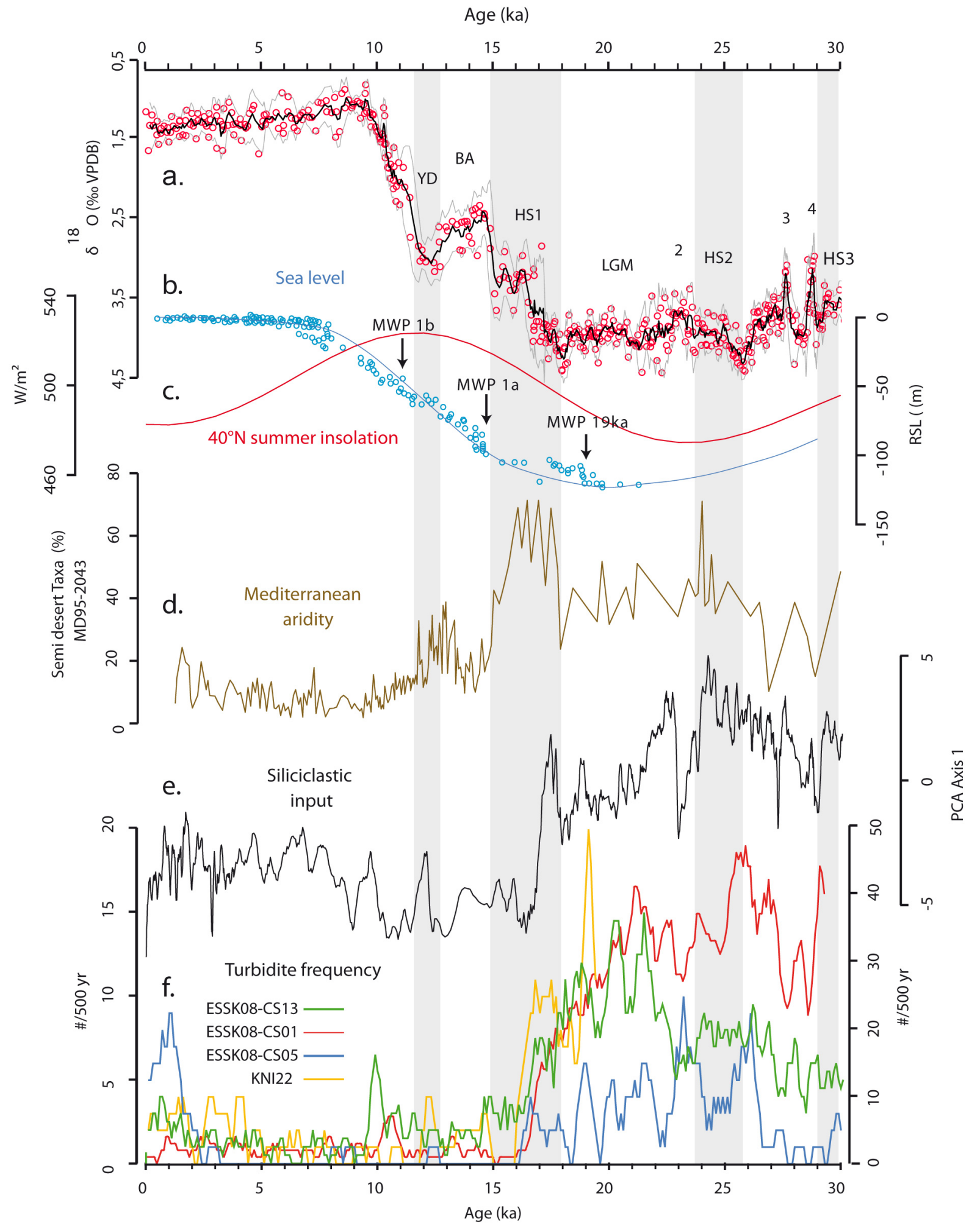

Figure 5. Evolution through the past $30 \mathrm{kyr}$ of $(a)$ the $\delta^{18} \mathrm{O}$ composite curve of Globigerina bulloides on the VSR (black line; BA = Bolling-Allerod period; HS = Heinrich stadials; LGM = Last Glacial Maximum; VPDB = Vienna Peedee belemnite; YD = Younger Dryas); (b) relative sea level (RSL), from Waelbroeck et al. (2002; line) and Clark et al. (2009; circles), inferred from radiocarbon and U/Th dating of corals (MPW = meltwater pulse); (c), summer insolation at $40^{\circ} \mathrm{N}$ (in W/ $\left./ \mathrm{m}^{3}\right) ;(d)$ Mediterranean aridity, inferred from percentage of semidesert taxa pollens from core MD95-2043 in the Alboran Sea (Fletcher and Sánchez-Goñi 2008); (e) siliciclastic input, deduced from principal-component analysis (PCA) axis 1 score of ESSK08-CS05 X-ray fluorescence core-scanner data; and $(f)$ turbidite frequency in the four cores. Note that the right-hand scale concerns core ESSK08-CS01, whereas left-hand scale concerns the other cores. ka= thousands of years ago. A color version of this figure is available online. 


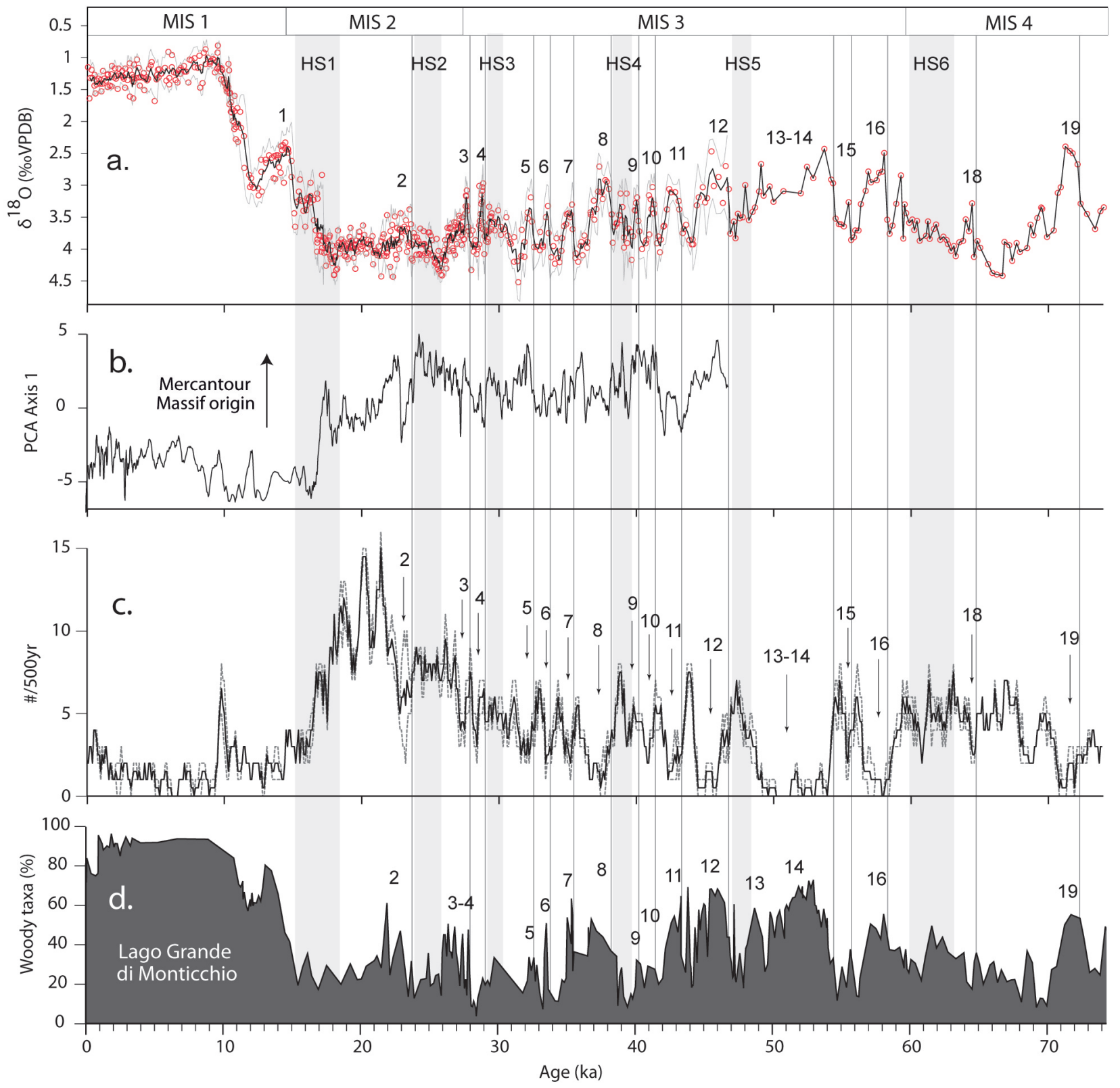

Figure 6. Evolution through the past $75 \mathrm{kyr}$ of $(a)$ the $\delta^{18} \mathrm{O}$ composite curve of Globigerina bulloides on the Var Sedimentary Ridge (line); see figure 3 for further details; $(b)$ siliciclastic input deduced from principal-components analysis (PCA) axis 1 score of ESSK08-CS05 X-ray fluorescence core-scanner data; $(c)$ turbidite frequency in core ESSK08-CS13 (dashed lines represent minimum and maximum error of visual counting); interstadials are indicated by black arrows; and $(d)$ pollen concentration of woody taxa in Lago Grande di Monticcio (Allen et al. 1999). The age model has been reshaped using the Greenland Ice Core Chronology 2005 timescale; following chronological interpretation of vegetation variability by Watts et al. (2000) and Fletcher et al. (2010), the previous age model (Allen et al. 1999|, based on counting annual layers, was conserved for age tuned between tie points. HS = Heinrich stadials; MIS = marine isotope stage; VPBD = Vienna Peedee belemnite. A color version of this figure is available online. 
valley after $16 \mathrm{ka}$. Indeed, such fast (with a large content of sands eroded from the channel) and thin flows hardly spilled over the (100-300-m-high) western and middle VSR but may have deposited sand beds downstream, where the elevation of the levee decreases significantly. As a result, the low frequency of turbidites and the low sedimentation rate observed in cores after $16 \mathrm{ka}$ (figs. 3, 5f) are, as previously suggested by Piper and Savoye (1993), more likely caused by flows bypassing the upper/ middle VSR, shifting the sedimentation preferentially to the downstream portion of the system, rather than by disconnection of the deep depositional system from the Var River in response to deglacial sea level change. This assumption is strongly supported by the absence of a continental shelf off the Var River, enabling a perennial rivercanyon connection through time (Savoye et al. 1993).

Before 16 ka (i.e., during the Pleistocene), overflows on the western and middle VSR were frequent, up to one event every 10-30 yr (fig. 5f). Turbidite beds are thick (several centimeters) and composed of mixed sediments. These beds were probably deposited by slow (carrying a large amount of mud) and thick currents with a duration of days to weeks (Piper and Savoye 1993; Mulder et al. 2001a, 2003). Given the absence of continental shelf, no morphological difference in the Var delta between lowstand and highstand conditions could have induced slide-related turbidity currents with such characteristics (Piper and Savoye 1993). So we assume that the characteristics of Pleistocene flows correspond more closely to flood-induced hyperpycnal currents (Mulder and Alexander 2001; Alexander and Mulder 2002; Piper and Normark 2009) originated from the Var River (Piper and Savoye 1993; Mulder et al. 1998, 2001a). The continental influence of such currents is supported by the low abundance of coccoliths in Pleistocene turbidite beds (Piper and Savoye 1993; Mulder and Alexander 2001). The high frequency of turbidites observed on the western $/ \mathrm{mid}$ dle VSR before $16 \mathrm{ka}$ may reflect that hyperpycnal currents spilling over the VSR occurred more frequently than during Termination 1 and the Holocene. This result does not necessarily reflect an increasing number of hyperpycnal events in the Var sediment-routing system but could indicate that a larger volume of sediments was involved during glacial times, at least during high-magnitude events (Piper and Normark 1983).

We conclude that variations in frequency of overflows recorded in cores from the western-tomiddle VSR mainly reflect changes in the magni- tude of hyperpycnal flows of Var River floods. Lowmagnitude events represent the main part of the sediment flux in the Var sediment-routing system (Mulder et al. 1997b, 1998) but have a very limited importance in the geological record, since they do not deposit sediments on the VSR, where they have the best chance of being preserved in the long term. Furthermore, high-magnitude events contributed sporadically to sediment flux but were very important for the interpretation of the geological record. Therefore, we cannot affirm that evolution of the frequency of high-magnitude hyperpycnal currents, observed in cores, is representative of variations in the sediment flux transiting the system. Nevertheless, this signal is mainly related to flood magnitude, and thus it contains information about the climate conditions that prevailed in the drainage area. Indeed, the capacity of a river to generate hyperpycnal flows with various frequency, magnitude, and duration depends on relationships between the suspended-sediment concentration and the water discharge (i.e., density contrast with seawater) that are highly sensitive to climate conditions (Mulder and Syvitsky 1995; Mulder et al. 1997b, 1998, 2003). For the Var River, Mulder et al. (1997b) demonstrated that, for a given water discharge, floods occurring after dry periods have an enhanced suspended-sediment concentration and hence are more likely to be transformed in hyperpycnal flows into the sea. Therefore, hyperpycnal activity could have been more sensitive to pure sediment-flux perturbations (due to variations in erosion/sediment availability) than to changes in sediment-flux variations arising from water discharge (Mulder et al. 2003). To verify this hypothesis, the following discussion focuses on the turbidity activity changes in reaction to climate change.

Climate Interpretation of Turbidite Frequency Records. The Last Glacial Maximum and Termination 1. The maximum of the VSR turbidite activity is observed between 30 and $16 \mathrm{ka}$ (fig. 5f), a period encompassing the global Last Glacial Maximum (LGM; 26-19.5 ka). During this period, Europe was characterized by a cold climate that led to extensive glaciation in the Alps (Ivy-Ochs et al. 2008) and in the Var River basin (Buoncristiani and Campy 2004). At that time, glaciers covered about $17 \%$ of the total Var drainage basin area (Jorry et al. 2011; figs. 1, 2).

Recently, numerical modeling of Alpine rivers predicted that LGM floods were characterized by both a lower frequency and a lower water discharge than those during the subsequent Bolling-Allerod (14.7-12.9 ka), Younger Dryas (12.9-11.7 ka), and 
Holocene periods (Kettner and Syvitski 2008, 2009). However, these studies showed that LGM floods transported a significantly higher sediment load, related to the large amount of sediments produced by glaciers. Savoye and Piper (1993) first suggested that the large number of turbidites observed on the VSR during the Pleistocene resulted from high-magnitude hyperpycnal flow of fluvioglacial Var floods with a high sediment load. This interpretation is supported by siliciclastic input variations presented in figure $5 e$. The Var watershed is mainly composed of marls and limestones, and the siliciclastic input appears to be essentially delivered by the metamorphic massif of Mercantour (fig. 1). During the LGM period, glaciers were located in two main valleys (the Vésubie and Tinée Valleys) that drain the Mercantour Massif (Buoncristiani and Campy 2004; fig. 1). As a result, siliciclastic sediments deposited during the LGM can be interpreted as glacier-derived sediments. Both siliciclastic/glacier-derived sediment input and turbidite frequency were high during glacial time and synchronously decreased at $16 \mathrm{ka}$ (fig. 5). Since this timing corresponds to the age of major glacial retreat reported in the Alps $(20-16 \mathrm{ka}$; Hinderer 2001; Ivy-Ochs et al. 2004, 2008; Schaefer et al. 2006), we assume that the 16-ka transition in the VSR turbidite sedimentation is explained by the decreasing impact of alpine glaciers on both erosion in and sediment delivery to the Var River. This finding is consistent with results from slackwater sediments from an eastern Mediterranean watershed in which a similar rapid change in flooding sediment origin from ice melt related to rainfall related occurred between 20 and $17 \mathrm{ka}$ (Woodward et al. 2008).

The D/O Cycles. Temporal changes in turbidite deposition recorded in core ESSK08-CS13 cover the past $70 \mathrm{kyr}$, including MIS3 and MIS4. The southern European climate during MIS3 was characterized by millennial-scale oscillations $(\mathrm{D} / \mathrm{O}$ cycles), with cold and arid periods (D/O stadials, including the Heinrich stadials) followed by relatively warm and wet periods (D/O interstadials). Turbidite activity on the VSR clearly responds to $\mathrm{D} / \mathrm{O}$ cycles through a stadial-high/interstadial-low turbidite activity pattern (fig. 6). This draws an inverse relationship between precipitation and turbidite accumulation that contrasts highly with other recent studies conducted on turbidite systems (Nakajima et al. 2007; Covault et al. 2010). This confirms that in the case of the Var sediment-routing system, in which sediment transport by hyperpycnal flow predominates, deep-sea sediment transfers are more reactive to pure sediment-flux perturbations (i.e., erosion/sediment availability) than to water-discharge changes (Mulder et al. 2003). We assume that these variations could be driven by variations in erosion induced by changes in glacier and vegetation cover.

Little is known about the response of alpine glaciers to climate oscillation during MIS 3 and the $\mathrm{D} / \mathrm{O}$ cycles, since the maximum extension of LGM glaciers erased former moraines. Siliciclastic/glacier-derived sediment inputs in the Var sediment-routing system remained high during the whole last glacial period (50-16 ka; fig. 6b). This suggests that glaciers could have existed during MIS 3 in the upper basin and stayed quite stable. Importantly, there is no relation between turbidite activity and the PC1 curve (siliciclasitc/ glacier-derived sediment inputs), suggesting that glaciers may have had a limited control over sediment transfers at that time.

Moreover, vegetation in southern Europe quickly responded to $\mathrm{D} / \mathrm{O}$ climate oscillations, with sparse vegetation cover under cold and arid stadial conditions (Allen et al. 1999; Sánchez Goñi et al. 2002; Combourieu Nebout et al. 2002; Fletcher and Sánchez Goñi 2008; Fletcher et al. 2010; fig. 6d). This probably enhanced runoff and erosion and thus induced a larger sediment supply in the Var watershed (e.g., Syvitski and Milliman 2007). Conversely, the development of vegetation cover in the watershed under wetter interstadial conditions would have contributed to stabilizing soils and limited runoff. The impact of vegetal cover on sediment transfer was probably exacerbated by the geomorphological characteristics of the watershed. Because of the high elevation (ca. 90\% above $500 \mathrm{~m}$ ) and relief, a small change in temperature corresponds to a large change in vegetation cover (especially forest cover; fig. 2). This pattern is correlated with alluvial stratigraphic studies that reveal aggradation of Mediterranean rivers linked to intense erosion of unvegetated soils during stadial intervals, while mean water discharge (i.e., volume) was greater during wetter interstadials, as attested by incision phases in Mediterranean rivers (Macklin et al. 2002, 2012; Woodward et al. 2008).

\section{Conclusions}

This study presents the first detailed millennialscale stratigraphic framework in the Var sedimentrouting system over the most recent glacial and interglacial intervals (i.e., the past $75 \mathrm{kyr}$ ), based on temporal changes in turbidite deposition in the 
western Mediterranean Sea. Turbidity activity on the VSR mainly reflects changes in magnitude of hyperpycnal flows spilling over the ridge, in relation with variations of the suspended-sediment concentration of the Var River floods. We show that this signal is sensitive to changes in pure sediment flux induced by climatic perturbations occurring inland. Precisely, erosion/sediment availability changes in response to (1) the presence or absence of glaciers in the drainage area and (2) the reduction or development of vegetation cover in response to $\mathrm{D} / \mathrm{O}$ climate swings. Our findings, based on an unprecedented resolution in turbidite sequences for the past $75 \mathrm{kyr}$, show that rivers can transmit high-frequency changes in sedimentflux changes to deep basins and that turbidity deposits can be used as archives of high-resolution land-to-sea transfers. As $66 \%$ of global rivers are able to produce hyperpycnal currents (Mulder and Syvitski 1995), the Var River represents a major case study for understanding the modulation of sediment transfer to the deep ocean through glacial/interglacial and millennial-timescale climate changes.

\section{A C KN OW LED G M EN T S}

We would like to acknowledge the ARTEMIS (Accélérateur pour la Recherche en sciences de la Terre, Environnement, Muséologie) Saclay and Poznan laboratories for having provided the radiocarbon dates. We thank N. Labourdette (Université Pierre et Marie Curie [UPMC]), J. Etoubleau (IFREMER), and M. Rovere (IFREMER) for their technical support and advice. The captains, crew members, and principal investigators of the 1996 NICASAR and 2008 ESSDIV cruises are warmly thanked for having contributed to the collection of high-quality sediment cores along the VSR. This project is funded by UPMC (Institut des Sciences de la Terre de Paris) and IFREMER (projects Sedimentary Systems and Geological Hazards).

\section{REFERENCES CITED}

Alexander, J., and Mulder, T. 2002. Experimental quasisteady density currents. Mar. Geol. 186:195-210.

Allen, J. R. M.; Brandt, U.; Brauer, A.; Hubberten, H.-W.; Huntley, B.; Keller, J.; Kraml, M.; et al. 1999. Rapid environmental changes in southern Europe during the last glacial period. Nature 400:740-743.

Allen, P. A. 2008. Time scales of tectonic landscapes and their sediment routing systems. In Gallagher, K.; Jones, S. J.; and Wainwright, J., eds. Landscape evolution: denudation, climate and tectonics over different time and space scales. Geol. Soc. Lond. Spec. Publ. 296:7-28.

Armitage, J. J.; Dunkley Jones, T.; Duller, R. A.; Whittaker, A. C.; and Allen, P. A. 2013. Temporal buffering of climate-driven sediment flux cycles by transient catchment response. Earth Planet. Sci. Lett. 369370:200-210.

Blum, M. D., and Törnqvist, T. E. 2000. Fluvial responses to climate and sea-level change: a review and look forward. Sedimentology 47:2-48.

Bond, G.; Broecker, W.; Johnsen, S.; McManus, J.; Labeyrie, L.; Jouzel, J.; and Bonani, G. 1993. Correlations between climate records from North Atlantic sediments and Greenland ice. Nature 365:143-147.

Bouma, A. H. 1962. Sedimentology of some flysch deposits. Amsterdam, Elsevier, 168 p.

Buoncristiani, J.-F., and Campy, M. 2004. The palaeogeography of the last two glacial episodes in France: the Alps and Jura. In Ehlers, J., and Gibbard, P., eds. Quaternary glaciations: extent and chronology. Developments in Quaternary science. Vol. 2, Pt. 1. Amsterdam, Elsevier, p. 101-110.
Cacho, I.; Grimalt, J. O.; Pelejero, C.; Canals, M.; Sierro, F. J.; Flores, J. A.; and Shackleton, N. 1999. DansgaardOeschger and Heinrich event imprints in Alboran Sea paleotemperatures. Paleoceanography 14:698-705.

Castelltort, S., and Van Den Driessche, J. 2003. How plausible are high-frequency sediment supply-driven cycles in the stratigraphic record? Sediment. Geol. 157:3-13.

Collier, R. E. L.; Leeder, M. R.; Trout, M.; Ferentinos, G.; Lyberis, E.; and Papatheodorou, G. 2000. High sediment yields and cool, wet winters: test of last glacial paleoclimates in the northern Mediterranean. Geology 28:999-1002.

Combourieu Nebout, N.; Turon, J. L.; Zahn, R.; Capotondi, L.; Londeix, L.; and Pahnke, K. 2002. Enhanced aridity and atmospheric high-pressure stability over the western Mediterranean during the North Atlantic cold events of the past 50 k.y. Geology 30:863-866.

Coulthard, T. J., and Van de Wiel, M. J. 2013. Climate, tectonics or morphology: what signals can we see in drainage basin sediment yields? Earth Surf. Dyn. 1:67-91.

Covault, J. A.; Romans, B. W.; Fildani, A.; McGann, M.; and Graham, S. A. 2010. Rapid climatic signal propagation from source to sink in a southern California sediment-routing system. J. Geol. 118:247-259.

Covault, J. A.; Romans, B. W.; Graham, S. A.; Fildani, A.; and Hilley, G. E. 2011. Terrestrial source to deep-sea sink sediment budgets at high and low sea levels: insights from tectonically active southern California. Geology 39:619-622. 
Dan, G.; Sultan, N.; and Savoye, B. 2007. The 1979 Nice harbour catastrophe revisited: trigger mechanism inferred from geotechnical measurements and numerical modelling. Mar. Geol. 245:40-64.

Dennielou, B.; Huchon, A.; Beaudouin, C.; and Berné, S. 2006. Vertical grain-size variability within a turbidite levee: autocyclicity or allocyclicity? A case study from the Rhône neofan, Gulf of Lions, western Mediterranean. Mar. Geol. 234:191-213.

Dubar, M., and Anthony, E. J. 1995. Holocene environmental change and river-mouth sedimentation in the Baie des Anges, French Riviera. Quat Res. 43: 329-343.

Fletcher, W. J., and Sánchez Goñi, M. F. 2008. Orbitaland sub-orbital-scale climate impacts on vegetation of the western Mediterranean basin over the last 48,000 yr. Quat. Res. 70:451-464.

Fletcher, W. J.; Sánchez Goñi, M. F.; Allen, J. R. M.; Cheddadi, R.; Combourieu-Nebout, N.; Huntley, B.; Lawson, I.; et al. 2010. Millennial-scale variability during the last glacial in vegetation records from Europe. Quat. Sci. Rev. 29:2839-2864.

Hinderer, M. 2001. Late Quaternary denudation of the Alps, valley and lake fillings and modern river loads. Geodin. Acta 14:231-263.

Hinderer, M., and Einsele, G. 2001. The world's large lake basins as denudation-accumulation systems and implications for their lifetimes. J. Paleolimnol. 26:355372.

Ivy-Ochs, S.; Kerschner, H.; Reuther, A.; Preusser, F.; Heine, K.; Maisch, M.; Kubik, P. W.; and Schlüchter, C. 2008. Chronology of the last glacial cycle in the European Alps. J. Quat. Sci. 23:559-573.

Ivy-Ochs, S.; Schäfer, J.; Kubik, P.; Synal, H.-A.; and Schlüchter, C. 2004. Timing of deglaciation on the northern Alpine foreland (Switzerland). Eclogae Geol. Helv. 97:47-55.

Jerolmack, D. J., and Paola, C. 2010. Shredding of environmental signals by sediment transport. Geophys. Res. Lett. 37:L19401.

Jorry, S. J.; Jégou, I.; Emmanuel, L.; Silva Jacinto, R.; and Savoye, B. 2011. Turbiditic levee deposition in response to climate changes: the Var Sedimentary Ridge (Ligurian Sea). Mar. Geol. 279:148-161.

Kettner, A. J., and Syvitski, J. P. M. 2008. Predicting discharge and sediment flux of the Po River, Italy since the Last Glacial Maximum. In de Boer, P.; Postma, G.; van der Zwan, K.; Burgess, P.; and Kukla, P., eds. Analogue and numerical modelling of sedimentary systems: from understanding to prediction. Chichester, Wiley, p. 171-189.

. 2009. Fluvial responses to environmental perturbations in the northern Mediterranean since the Last Glacial Maximum. Quat. Sci. Rev. 28:2386-2397.

Khripounoff, A.; Crassous, P.; Lo Bue, N.; Dennielou, B.; and Silva Jacinto, R. 2012. Different types of sediment gravity flows detected in the Var submarine canyon (northwestern Mediterranean Sea). Prog. Oceanogr. 106:138-153.
Khripounoff, A.; Vangriesheim, A.; Crassous, P.; and Etoubleau, J. 2009. High frequency of sediment gravity flow events in the Var submarine canyon (Mediterranean Sea). Mar. Geol. 263:1-6.

Macklin, M. G.; Fuller, I. C.; Lewin, J.; Maas, G. S.; Passmore, D. G.; Rose, J.; Woodward, J. C.; Black, S.; Hamlin, R. H. B.; and Rowan, J. S. 2002. Correlation of fluvial sequences in the Mediterranean basin over the last $2000 \mathrm{ka}$ and their relationship to climate change. Quat. Sci. Rev. 21:1633-1641.

Macklin, M. G.; Lewin, J.; and Woodward, J. C. 2012. The fluvial record of climate change. Philos. Trans. R. Soc. A 370:2143-2172.

Martrat, B.; Grimalt, J. O.; Lopez-Martinez, C.; Cacho, I.; Sierro, F. J.; Flores, J. A.; Zahn, R.; Canals, M.; Curtis, J. H.; and Hodell, D. A. 2004. Abrupt temperature changes in the western Mediterranean over the past 250,000 years. Science 306:1762-1765.

Mas, V. 2009. Caractérisation de l'activité hydrosédimentaire dans le système turbiditique du Var (NO Méditerranée) et de son enregistrement dans l'archive sédimentaire. $\mathrm{PhD}$ thesis, Université Bordeaux I.

Meybeck, M., and Vörösmarty, C. 2005. Fluvial filtering of land-to-ocean fluxes: from natural Holocene variations to Anthropocene. C. R. Geosci. 337:107-123.

Migeon, S.; Mulder, T.; Savoye, B.; and Sage, F. 2006. The Var turbidite system (Ligurian Sea, northwestern Mediterranean)-morphology, sediment supply, construction of turbidite levee and sediment waves: implications for hydrocarbon reservoirs. Geo-Mar. Lett. 26:361-371.

- 2012. Hydrodynamic processes, velocity structure and stratification in natural turbidity currents: results inferred from field data in the Var turbidite system. Sediment. Geol. 245-246:48-62.

Migeon, S.; Savoye, B.; Zanella, E.; Mulder, T.; Faugères, J. C.; and Weber, O. 2001. Detailed seismic-reflection and sedimentary study of turbidite sediment waves on the Var Sedimentary Ridge (SE France): significance for sediment transport and deposition and for the mechanisms of sediment-wave construction. Mar. Petrol. Geol. 18:179-208.

Milliman, J. D., and Syvitski, J. P. M. 1992. Geomorphic/ tectonic control of sediment discharge to the ocean: the importance of small mountainous rivers. J. Geol. 100:525-544.

Moreno, A.; González-Sampériz, P.; Morellón, M.; Valero-Garcés, B. L.; and Fletcher, W. J. 2012. Northern Iberian abrupt climate change dynamics during the last glacial cycle: a view from lacustrine sediments. Quat. Sci. Rev. 36:139-153.

Moreno, A.; Valero-Garcés, B.; González-Sampériz, P.; and Rico, M. 2008. Flood response to rainfall variability during the last 2000 years inferred from the Taravilla Lake record (Central Iberian Range, Spain). J. Paleolimnol. 40:943-961.

Mulder, T., and Alexander, J. 2001. The physical character of subaqueous sedimentary density flows and their deposits. Sedimentology 48:269-299. 
Mulder, T.; Migeon, S.; Savoye, B.; and Faugères, J. C. 2001a. Inversely graded turbidite sequences in the deep Mediterranean: a record of deposits from floodgenerated turbidity currents? Geo-Mar. Lett. 21:8693.

Mulder, T.; Migeon, S.; Savoye, B.; and Jouanneau, J.-M. $2001 b$. Twentieth century floods recorded in the deep Mediterranean sediments. Geology 29:1011-1014.

Mulder, T.; Savoye, B.; Piper, D. J. W.; and Syvitski, J. P. M. 1998. The Var submarine sedimentary system: understanding Holocene sediment delivery processes and their importance to the geological record. In Stoker, M. S.; Evans, D.; and Cramp, A., eds. Geological processes on continental margins: sedimentation, mass-wasting and stability. Geol. Soc. Lond. Spec. Publ. 129:145-166.

Mulder, T.; Savoye, B.; and Syvitski, J. P. M. $1997 a$. Numerical modelling of a mid-sized gravity flow: the 1979 Nice turbidity current (dynamics, processes, sediment budget and seafloor impact). Sedimentology 44:305-326.

Mulder, T.; Savoye, B.; Syvitski, J. P. M.; and Parize, O. 1997b. Des courants de turbidité hyperpycnaux dans la tête du canyon du Var? données hydrologiques et observations de terrain. Oceanol. Acta 20:607-626.

Mulder, T., and Syvitski, J. P. M. 1995. Turbidity currents generated at river mouths during exceptional discharges to the world oceans. J. Geol. 103:285-299.

- 1996. Climatic and morphologic relationships of rivers: implications of sea-level fluctuations on river loads. J. Geol. 104:509-523.

Mulder, T.; Syvitski, J. P. M.; Migeon, S.; Faugères, J.-C.; and Savoye, B. 2003. Marine hyperpycnal flows: initiation, behavior and related deposits. A review. Mar. Petrol. Geol. 20:861-882.

Nakajima, T., and Itaki, T. 2007. Late Quaternary terrestrial climatic variability recorded in deep-sea turbidites along the Toyama Deep-Sea Channel, central Japan Sea. Palaeogeogr. Palaeoclimatol. Palaeoecol. 247:162-179.

NGRIP (North Greenland Ice Core Project) Members. 2004. High-resolution record of Northern Hemisphere climate extending into the last interglacial period. Nature 431:147-151.

Piper, D. J. W., and Normark, W. R. 1983. Turbidite depositional patterns and flow characteristics, Navy Submarine Fan, California Borderland. Sedimentology 30:681-694.

- 2009. Processes that initiate turbidity currents and their influence on turbidites: a marine geology perspective. J. Sediment. Res. 79:347-362.

Piper, D. J. W., and Savoye, B. 1993. Processes of late Quaternary turbidity current flow and deposition on the Var deep-sea fan, north-west Mediterranean Sea. Sedimentology 40:557-582.

Rasmussen, S. O.; Andersen, K. K.; Svensson, A. M.; Steffensen, J. P.; Vinther, B. M.; Clausen, H. B.; Siggaard-Andersen, M. L.; et al. 2006. A new Green- land ice core chronology for the last glacial termination. J. Geophys. Res. Atmos. 111:D06102.

Reimer, P. J.; Baillie, M. G. L.; Bard, E.; Bayliss, A.; Beck, J. W.; Blackwell, P. G.; Ramsey, C. B.; et al. 2009. IntCal09 and Marine09 radiocarbon age calibration curves, 0-50,000 years cal BP. Radiocarbon 51:1111-1150.

Romans, B. W.; Normark, W. R.; McGann, M. M.; Covault, J. A.; and Graham, S. A. 2009. Coarse-grained sediment delivery and distribution in the Holocene Santa Monica Basin, California: implications for evaluating source-to-sink flux at millennial time scales. Geol. Soc. Am. Bull. 121:1394-1408.

Sage, L. 1976. La sédimentation à l'embouchure d'un fleuve côtier méditerranéen: le Var. Université de Nice.

Sánchez Goñi, M.; Cacho, I.; Turon, J.; Guiot, J.; Sierro, F.; Peypouquet, J.; Grimalt, J.; and Shackleton, N. 2002. Synchroneity between marine and terrestrial responses to millennial scale climatic variability during the last glacial period in the Mediterranean region. Clim. Dyn. 19:95-105.

Savoye, B.; Piper, D. J. W.; and Droz, L. 1993. PlioPleistocene evolution of the Var deep-sea fan off the French Riviera. Mar. Petrol. Geol. 10:550-571.

Schaefer, J. M.; Denton, G. H.; Barrell, D. J.; Ivy-Ochs, S.; Kubik, P. W.; Andersen, B. G.; Phillips, F. M.; Lowell, T. V.; and Schlüchter, C. 2006. Near-synchronous interhemispheric termination of the last glacial maximum in mid-latitudes. Science 312:1510-1513.

Schumm, S. A. 1977. The fluvial system. New York, Wiley, $338 \mathrm{p}$.

Sierro, F. J.; Andersen, N.; Bassetti, M. A.; Berné, S.; Canals, M.; Curtis, J. H.; Dennielou, B.; et al. 2009. Phase relationship between sea level and abrupt climate change. Quat. Sci. Rev. 28:2867-2881.

Simpson, G., and Castelltort, S. 2012. Model shows that rivers transmit high-frequency climate cycles to the sedimentary record. Geology 40:1131-1134.

Skene, K. I., and Piper, D. J. W. 2003. Late Quaternary stratigraphy of Laurentian Fan: a record of events off the eastern Canadian continental margin during the last deglacial period. Quat. Int. 99-100:135-152.

Skene, K. I.; Piper, D. J. W.; and Hill, P. S. 2002. Quantitative analysis of variations in depositional sequence thickness from submarine channel levees. Sedimentology 49:1411-1430.

Sternai, P.; Herman, F.; Valla, P. G.; and Champagnac, J.-D. 2013. Spatial and temporal variations of glacial erosion in the Rhône valley (Swiss Alps): insights from numerical modeling. Earth Planet. Sci. Lett. 368:119-131.

Svensson, A.; Andersen, K. K.; Bigler, M.; Clausen, H. B.; Dahl-Jensen, D.; Davies, S. M.; Johnsen, S. J.; et al. 2008. A 60000 year Greenland stratigraphic ice core chronology. Clim. Past 4:47-57.

Syvitski, J. P. M., and Milliman, J. D. 2007. Geology, geography, and humans battle for dominance over the 
delivery of fluvial sediment to the coastal ocean. J. Geol. 115:1-19.

Toucanne, S.; Zaragosi, S.; Bourillet, J.-F.; Dennielou, B.; Jorry, S. J.; Jouet, G.; and Cremer, M. 2012. External controls on turbidite sedimentation on the glacially-influenced Armorican margin (Bay of Biscay, western European margin). Mar. Geol. 303-306:137153.

Woodward, J. C.; Hamlin, R. H. B.; Macklin, M. G.; Hughes, P. D.; and Lewin, J. 2008. Glacial activity and catchment dynamics in northwest Greece: long-term river behaviour and the slackwater sediment record for the last glacial to interglacial transition. Geomorphology 101:44-67.

Zaragosi, S.; Bourillet, J.-F.; Eynaud, F.; Toucanne, S.; Denhard, B.; Van Toer, A.; and Lanfumey, V. 2006. The impact of the last European deglaciation on the deepsea turbidite systems of the Celtic-Armorican margin (Bay of Biscay). Geo-Mar. Lett. 26:317-329.26: 317-329. 